\title{
The effect of fire intensity on vegetation succession on a sub-xeric heath during ten years after wildfire
}

\author{
Lasse Ruokolainen ${ }^{1} \&$ Kauko Salo²
}

1) Department of Ecology and Evolutionary Biology, P.O. Box 65, Fl-00014 University of Helsinki,
Finland (e-mail: lasse.ruokolainen@helsinki.fi)
2) Finnish Forest Research Institute, Joensuu Research Unit, P.O. Box 68, FI-80101 Joensuu,
Finland (e-mail: kauko.salo@metla.fi)

Received 14 Sep. 2007, revised version received 11 Dec. 2007, accepted 15 Jan. 2008

Ruokolainen, L. \& Salo, K. 2009: The effect of fire intensity on vegetation succession on a subxeric heath during ten years after wildfire. - Ann. Bot. Fennici 46: 30-42.

Many studies indicate that fire intensity has a marked effect on subsequent vegetation recovery. However, evidence from natural fires is still sparse. We studied vegetation succession during ten years after a wildfire on a sub-xeric, pine dominated coniferous forest. The fire affected four adjacent patches differently and thus created a natural fire intensity gradient. Postfire vegetation data was analysed using non-metric multidimensional scaling and MANOVA. The clearest indication of fire intensity was provided by herbaceous colonizers. Recovering dwarf shrub cover and residual and invader moss cover provided additional evidence for observed differences between the four areas. Despite of initial dissimilarity, community composition became increasingly similar on the different areas during the study period. In conclusion, variation in fire intensity had a clear impact on postfire recovery in natural conditions. Fire disturbance also clearly enhanced local species richness and diversity. Our results indicate that habitat factors play a considerable role in the nature of vegetation recovery following wildfire.

Key words: fire intensity, forest fire, non-metric multidimensional scaling, species richness, vegetation succession

\section{Introduction}

Fire is a natural factor in the boreal forest ecosystem. In addition to its importance as a landscape-shaping agent (Heinselman 1973, Johnson 1992), frequent fires also maintain the diversity and long-term stability of the forests (Heinselman 1973, Zackrisson 1977, Turner \& Romme 1994, Wardle et al. 1997). Fire promotes the reinvasion of early successional species in burned areas, and although in many instances the post- fire community is mainly composed of surviving individuals (Foster 1985, Turner et al. 1997), it has a positive effect on biodiversity (Trabaud \& Lepart 1980, Armour et al. 1984, Ruokolainen \& Salo 2006b). Furthermore, for example many plant species have evolved to depend upon fire for their regeneration (Shafi \& Yarranton 1973), and thus if fires are not maintained in the landscape such species will eventually be lost from regional floras.

In addition to its influence on vegetation, fire 
induces changes in the biological, physical and chemical properties of the soil. The removal of the vegetation and the topsoil initially reduce site nutrients (Feller 1982, 1983, Simard et al. 2001, Arocena \& Opio 2003), particularly nitrogen and sulphur. However, soil temperature, cation availability and $\mathrm{pH}$ increase as a result of burning (Feller 1982, Simard et al. 2001, Arocena \& Opio 2003), which promotes soil microbial activity resulting in increased decomposition rate and nutrient turnover (Pietikäinen \& Fritze 1992). These effects promote the initial vegetation succession.

The most important fire related characteristic is its intensity of humus reduction (Schimmel \& Granström 1996). Fire intensity affects the pattern of vegetation recovery, community dynamics and soil processes. Moreover, the intensity of a wildfire determines the proportions of different colonization strategies present in the recovering community (Schimmel \& Granström 1996). As fire intensity increases, the abundances of resprouting species and species germinating from the seed bank are decreased, whereas the abundance of invading species (those that colonize through dispersal alone) increase. Fire intensity is also known to directly affect nutrient losses (Raison 1979), and subsequent increase in nutrient availability may also be related to fire intensity (Pietikäinen \& Fritze 1992).

Despite of its relative importance, fire intensity has rarely been studied in association with wildfires (Turner et al. 1997), which is probably due to the uncertainty of fire occurrence and the stochastic behaviour of the fire front. Thus, the effects of fire intensity on vegetation processes are mostly studied in experimental conditions (Schimmel 1993). In this paper we present a study conducted on the Kitsi forest fire area, where a wildfire created a mosaic of differently affected patches in a sub-xeric heath forest in 1993. The aim of this study was to determine whether vegetation development differed between sites that had been differently affected by fire, i.e., having different fire intensity. Our hypothesis that fire intensity will affect plant succession was tested with multivariate analysis of vegetation data, collected during ten years after a wildfire.

\section{Materials and methods}

\section{Study area}

The forest study area $\left(63^{\circ} 16^{\prime} \mathrm{N}, 30^{\circ} 45^{\prime} \mathrm{E}\right)$ is located in North Karelia, eastern Finland. The area is located within the mid-boreal climatic zone, which is in the eastern Finland characterized by relatively continental weather conditions. According to the fire chronology, the study area has burned several times during the past 400 years (Lehtonen \& Huttunen 1997). The latest fire started 7 June 1992 after broadcast burning, approximately one kilometre away from our study area. This fire affected an area of 137 ha, of which 55 ha belonged to the study area. The oldest living trees in the area were 156 years old at the time of the fire.

The study area is characterized by nutrient-poor mineral soil, the dominant tree species being scotch pine (Pinus sylvestris). Other tree species include Norway spruce (Picea abies) and birches (Betula pendula, B. pubescens). In the Finnish forest type classification system the forest was classified as Empetrum-Vaccinium type (EVT).

\section{Field methods}

After the fire a total of 22 permanent sample plots (each $10 \times 10 \mathrm{~m}$ ) were established in the area (Fig. 1) at two adjacent sites, Jäkäläkangas and Pöytäkangas. At Jäkäläkangas, 14 plots were established on four areas left by ground and severe canopy fire (100\% tree mortality) (A), ground fire on a clear-cut patch (B), ground fire and light canopy fire $(<50 \%$ tree mortality) (C), and unaffected control stand (Control J). At Pöytäkangas eight plots were established on two areas left by ground fire (D) and an unaffected control stand (Control P). The plots were randomly placed within each area in pairs, and within each pair the plots were at least 5 meters apart. Details considering the sampling design are described in Table 1. According to the behaviour of the fire, areas A-D were assumed to have been differently affected. These areas are hereafter referred to as 'treatments'. We realize that the selected control areas do not 


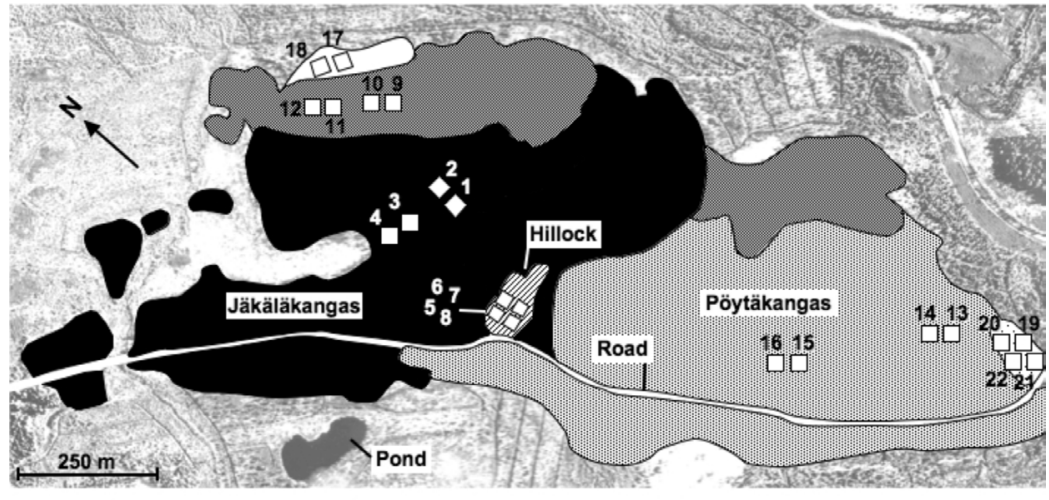

A: Ground and tree canopy fire, all trees died (numbers 1-4)

B: Ground fire on treeless figure (Hillock) (numbers 5-8)

C: Ground and tree canopy fire (numbers 9-12)

D: Ground fire (numbers 13-16)

Control J (numbers 17-18)

Control P (numbers 19-22)
Fig. 1. Sampling design within the study area in eastern Finland. White squares represent permanent sampling plots. The plots are not in scale, minimum distance between two plots $=5 \mathrm{~m}$. completely represent the pre-burned conditions in the burned areas. However, as pre-burned data were not available (which often is the case with wildfires), we considered the control areas to adequately represent conditions in the absence of fire. According to dendrochronological analysis, the control stands were on average 150 years old.

The sample plots were sampled for plant species composition and percent coverage. In addition, four humus samples were taken beside each sample plot. Nomenclature follows Hämet-Ahti et al. (1998) for vascular plants and Holmåsen (1998) for bryophytes and lichens.

\section{Data analysis}

Coverage values (percentages) for plant species, observed each year in the permanent sample plots, were used to construct a site: $x$ species matrix with 70 objects (sites) and 82 descriptors (species). This matrix was used to run a non-metric multidimensional scaling (NMDS) analysis (e.g. Minchin 1987), in order to find out whether there were any differences in vegetation composition between the 'treatments' and controls. This analysis was run in R ver. 2.2 .0 (http:// www.R-project.org) under the Vegan package, with the metaMDS function. By default, this function performs a Wisconsin double standardi-

Table 1. Details considering the sampling design. Letters A-D refer to different sites within the study area, being differently affected by the fire. Total $n=70$.

\begin{tabular}{lccrl}
\hline Area & Number of plots & $\begin{array}{c}\text { Sampling events } \\
\text { (years after fire) }\end{array}$ & $n$ & Notes \\
\hline A & 4 & $1,3,5,10$ & 16 & Plots established in 1993 \\
B & 4 & $2,3,5,10$ & 16 & Plots established in 1994 \\
C & 4 & $1,3,5,10$ & 16 & Plots established in 1993 \\
D & 4 & 5,10 & 8 & Plots established in 1997 \\
Control on Jäkäläkangas & 2 & $3,5,10$ & 6 & $\begin{array}{l}\text { Plots established in 1995, } \\
\text { only two plots due to lack } \\
\text { of available space }\end{array}$ \\
Control on Pöytäkangas & & & 8 & Plots established in 1997
\end{tabular}




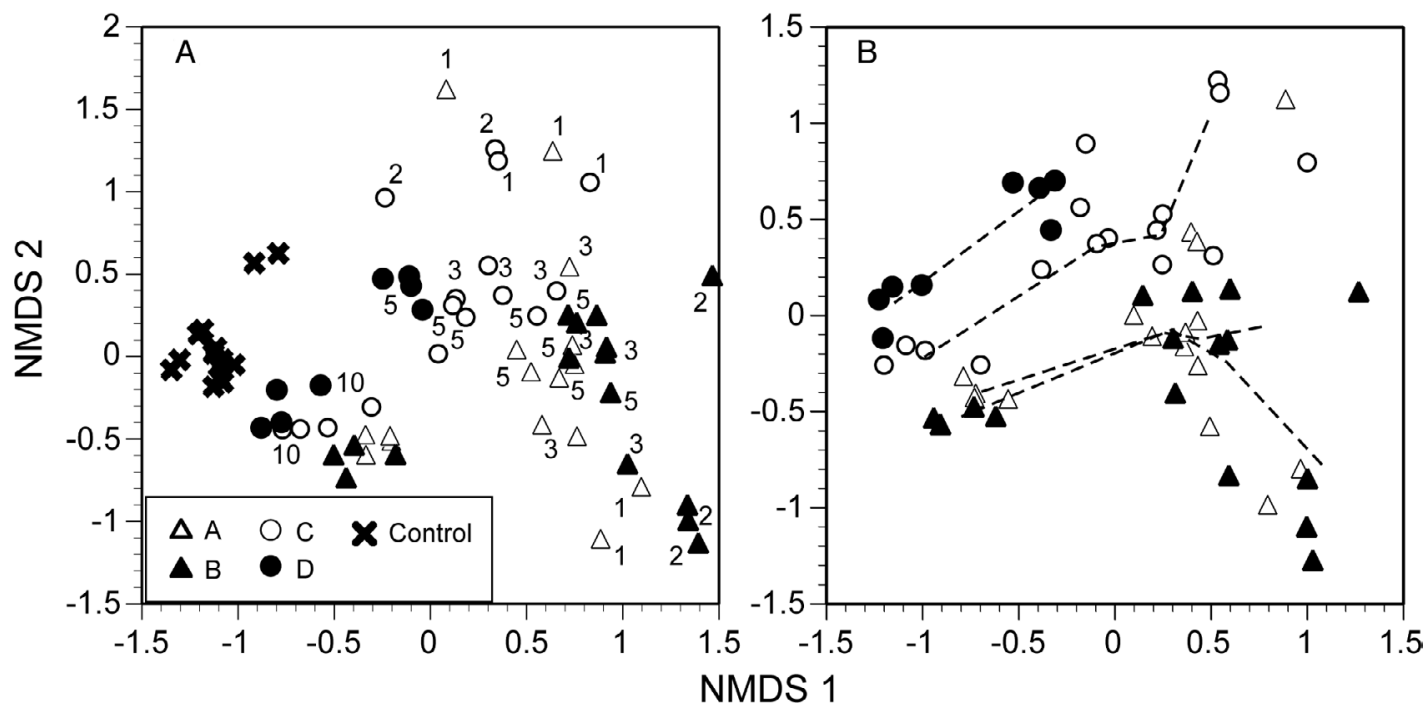

Fig. 2. NMDS ordination (based on Bray-Curtis dissimilarity) diagrams: (A) control plots included, and (B) control plots omitted. Symbols refer to different fire intensity 'treatments'. Data points represent permanent sampling plots $1,2,3,5,10$, and $>80$ (control) years after disturbance. Letters in the legend refer to fire intensity 'treatments'. In (B) dashed lines connect yearly centroids, representing succession trajectories.

zation (standardization of species and site) and a square root transformation (given that there are values $>50$, which was the case) to the data. The ordination was based on the widely used BrayCurtis dissimilarity, which is the complement of the Steinhaus $\left(S_{\mathrm{S}}\right)$ similarity index:

$$
S_{\mathrm{S}}=2 W /(A+B),
$$

where $W$ is the sum of minimum abundances of species shared by two sites and $A$ and $B$ are the total abundances of species present at these two sites (Legendre \& Legendre 1998). This association measure was selected namely because it is familiar to most community ecologists. However, the NMDS solution was relatively insensitive to the underlying distance measure.

After a stable solution is reached, the metaMDS function rotates the final configuration to its principal components in order to ensure that the obtained dimensions corresponded to maximum variation in the data. The final configuration is also centered and scaled to half-change. Half-change scaling scales the configuration so that one unit along an ordination axis means halving of community similarity from replicate similarity (Økland 1990). We required the final configuration to be two-dimensional.

Many studies have shown that fire intensity has a potential influence on post fire vegetation recovery (Schimmel 1993, Schimmel \& Granström 1996, Wang \& Kendal 2005) and according to Økland (2000) it is likely to be one of the most important determinants of postfire species composition. Against this background we tested how well the NMDS ordination reflected the fire intensity gradient in our data. This was done using multivariate analysis of variance (MANOVA), where statistical significances were estimated using 999 permutations (the $F$ values for all model parameters are calculated repeatedly after randomizing the response variables, the original $F$ values are then compared with the resulting $F$ distributions). The results were used to justify further tests. This analysis was run with a NMDS solution obtained without the control plots, as the differences between the fire intensity 'treatments' were of main interest here. In order to account for the non-independence of observation between years, we fit the model with fire intensity, year since fire, and their interaction as predictors and the two NMDS-axes as the response. This is a simple way of analysing data with repeated measurements (Crawley 2002). 
The ordination solution (Fig. 2) indicated that time since fire might have a non-linear effect on vegetation composition. Therefore we introduced succession year as a second-degree polynomial, in order to account for potential problems with non-linearity. A second-degree polynomial is also a useful proxy, if plant species are assumed to have some sort of optimum-type development along a temporal gradient (due to responses in gradual changes in, e.g., soil resources and interspecific competition).

We have previously shown that variation in species abundances is to some extent related to fire intensity in this data set (Ruokolainen \& Salo 2006a). Here we took the analysis further by testing whether the total abundances of different plant life-form groups varied between the fire intensity 'treatments' and different years along initial succession. This was tested with MANOVA (same predictors as above), and as the dependent variables were not normally distributed statistical significance was estimated with 999 permutations. Again, control plots were omitted from the analysis, as the primary interest was in the differences between 'treatments'. In addition to plant life-forms, we also tested plant diversity, given by Shannon's $H$, against fire intensity and time (and their interaction). Following Pielou (1975) Shannon's $H$ was calculated as

$$
H=\sum_{i=1}^{S} p_{i} \ln p_{i}
$$

where $S$ is the total number of species in a plot, $p_{i}$ is the proportion of the $i$ th species, and $\ln$ is the

Table 2. MANOVA table representing the ability of the two NMDS-dimensions to reflect the underlying fire-intensity and temporal gradient. Year is here a second-degree polynomial of the actual succession year. Significances tested with 999 permutations. The model explains $66 \%$ of variation along the first dimension (NMDS1), and 52\% along the second dimension (NMDS2).

\begin{tabular}{lrrrr}
\hline Source of variation & df & $\begin{array}{c}\text { Wilks' } \\
\text { lambda }\end{array}$ & $F$ & $p$ \\
\hline Fire intensity & 3 & 0.45 & 7.30 & $<0.001$ \\
Year & 2 & 0.46 & 10.37 & $<0.001$ \\
Fire $\times$ Year & 5 & 0.52 & 3.42 & 0.005 \\
Residuals & 45 & & & \\
\hline
\end{tabular}

natural logarithm. In order to fulfil the requirements of parametric testing, we transformed the plant life-form groups with a square root function. These analyses were also run in $\mathrm{R}$ ver. 2.2.0. We realize that the simple method adopted here, for analysing data with repeated measurements, is not very elegant. Here we did not use repeated measures ANOVA, as it requires a fully balanced design. Since we did not have vegetation estimates for all 'treatments' at each year (Table 1), we chose to use a simpler method. Moreover, as our main aim was to analyze differences in fire intensity and not in succession time, we feel that pseudoreplication was not a major concern in the analyses.

\section{Results}

A separation between different fire intensities could be observed in the ordination diagrams (Fig. 2A). Also, control plots were still clearly separated from the burned sites ten years after the fire, which implies that it had a long-lasting effect on understorey vegetation. With the control plots omitted from the data, fire intensity, succession year, and their interaction explained together $66 \%$ of the total variation on the first NMDS-dimension and 52\% on the second (Table $2)$. The first dimension mainly reflected the temporal gradient whereas fire intensity was evenly reflected by both dimensions. It was evident from the ordination diagram (Fig. 2B) that succession proceeded differently at the ground fire sites (C and D) as compared with that at the canopy fire site (A) and the burned clear-cut patch (B). Moreover, the ground fire sites where also different from each other with respect to plant succession. In contrast, sites A and B were relatively similar with each other. These observations were corroborated by the significant interaction between fire intensity and succession year (different slope/curvature in linear regression) in explaining the variation along the NMDS dimensions (Table 2).

In order to find out which vegetation components were behind the observed patterns, the abundance of plant life-form groups and overall species diversity was tested against fire intensity, succession year, and their interaction (the 
complete list of observed species is given in the Appendix). These analyses revealed that most differences between the sites were due to dwarf shrub cover (Table 3). Most variation between succession years was due to changes in bryophyte and dwarf shrub cover, respectively. Dwarf shrub cover was on average highest at site $\mathrm{D}$ and lowest at site B (Fig. 3). Interestingly, average dwarf shrub cover was higher at site A than site C. This was at least partly due to Calluna vulgaris namely occurring only at site A. As indicated by the total dwarf shrub cover, the average cover of the dominant species (Vaccinium vitisidaea and V. myrtillus) seemed to differ to some extent between the 'treatments' (Fig. 4). Site D had the highest cover of both species, while site $\mathrm{B}$ had the lowest cover. Both species had a relative similar cover at sites A and C. Tree seedling cover did not differ significantly between the sites (Table 3).

Herb cover also varied significantly between the sites (Table 3). Herbs were on average more abundant on B than A, whereas they were relatively low in abundance on $\mathrm{C}$ and almost absent on D (Fig. 3). In relative terms herb cover was rather low and constituted mainly of Epilobium angustifolium and Taraxacum officinale individuals. The dominant herb, E. angustifolium, had a relatively higher cover at sites $\mathrm{A}$ and $\mathrm{B}$ as compared with that at sites $\mathrm{C}$ and D (Fig. 4). Also, site B had on average a higher cover of E. angustifolium than site A. Variation in grass cover between sites had a clear temporal effect (Table 3 ). Initially grasses were more abundant at the more severely affected sites (A, B), but later on grass cover was highest at sites $\mathrm{B}$ and $\mathrm{C}$ with intermediate (in relative terms) disturbance intensity. These differences were namely due to variable recovery of Deschampsia flexuosa (Appendix).

Differences in bryophyte cover between sites were evident during the three first years in the data (Fig. 5). These differences were mostly due to bryophyte species composition. In general, sites A and B had mostly pioneer species (Ceratodon purpureus and Polytrichum juniperinum) whereas sites $\mathrm{C}$ and $\mathrm{D}$ had also many residual species (e.g. Pleurozium schreberi and Dicranum polysetum) in addition to pioneer species. However, cover of the dominant pioneer species,
C. purpureus and $P$. juniperinum, was quite similar between the four sites (Fig. 4), except that site D had the lowest cover of P. juniperinum and site A retained the highest cover of $C$. purpureus during the study period. Throughout the study period lichens were on average more abundant at sites $\mathrm{A}$ and $\mathrm{B}$ than at sites $\mathrm{C}$ and $\mathrm{D}$ (with the exception of year 10 when lichen cover was approximately the same at sites A, B and D).

A total of 82 species were recorded during the study period (Appendix); 25 (30\%) species were only observed in the burned areas, whereas

Table 3. ANOVA table for tests between plant life form groups and fire intensity, succession year (Year), and their interaction (Fire $\times$ Year). Year is here a second-degree polynomial of the actual succession year. Relative (\%) cover of species groups was used as a dependent variable in the analysis. Global statistics from a MANOVA model (Fire intensity, Year and Fire $\times$ Year, respectively): Wilks' lambda $=0.06,0.10,0.33$; $F=10.74,78.37,1.71 ; p=<0.001,<0.001,0.004$. Degrees of freedom (df) as in Table 2. Significances tested with 999 permutations.

\begin{tabular}{|c|c|c|c|c|}
\hline Response & $\begin{array}{l}\text { Source of } \\
\text { variation }\end{array}$ & MS & $F$ & $p$ \\
\hline \multirow[t]{4}{*}{ Trees } & Fire intensity & 0.60 & 1.54 & 0.236 \\
\hline & Year & 9.93 & 25.40 & $<0.001$ \\
\hline & Fire $\times$ Year & 0.74 & 1.88 & 0.116 \\
\hline & Residuals & 0.39 & & \\
\hline \multirow[t]{4}{*}{ Shrubs } & Fire intensity & 46.90 & 53.70 & $<0.001$ \\
\hline & Year & 99.05 & 113.42 & $<0.001$ \\
\hline & Fire $\times$ Year & 1.93 & 2.21 & 0.055 \\
\hline & Residuals & 0.87 & & \\
\hline \multirow[t]{4}{*}{ Grasses } & Fire intensity & 1.40 & 3.40 & 0.021 \\
\hline & Year & 5.66 & 13.74 & $<0.001$ \\
\hline & Fire $\times$ Year & 0.16 & 0.38 & 0.875 \\
\hline & Residuals & 0.41 & & \\
\hline \multirow[t]{4}{*}{ Herbs } & Fire intensity & 22.75 & 18.95 & $<0.001$ \\
\hline & Year & 19.77 & 16.46 & $<0.001$ \\
\hline & Fire $\times$ Year & 3.22 & 2.68 & 0.030 \\
\hline & Residuals & 1.20 & & \\
\hline \multirow[t]{4}{*}{ Bryophytes } & Fire intensity & 23.94 & 15.96 & $<0.001$ \\
\hline & Year & 210.37 & 140.26 & $<0.001$ \\
\hline & Fire $\times$ Year & 2.21 & 1.48 & 0.224 \\
\hline & Residuals & 1.50 & & \\
\hline \multirow[t]{4}{*}{ Lichens } & Fire intensity & 1.49 & 12.09 & $<0.001$ \\
\hline & Year & 45.62 & 370.83 & $<0.001$ \\
\hline & Fire $\times$ Year & 0.47 & 3.84 & 0.004 \\
\hline & Residuals & 0.12 & & \\
\hline \multirow[t]{4}{*}{ Shannon's $H$} & Fire intensity & 0.60 & 9.96 & $<0.001$ \\
\hline & Year & 3.67 & 61.26 & $<0.001$ \\
\hline & Fire $\times$ Year & 0.15 & 2.55 & 0.038 \\
\hline & Residuals & 0.06 & & \\
\hline
\end{tabular}



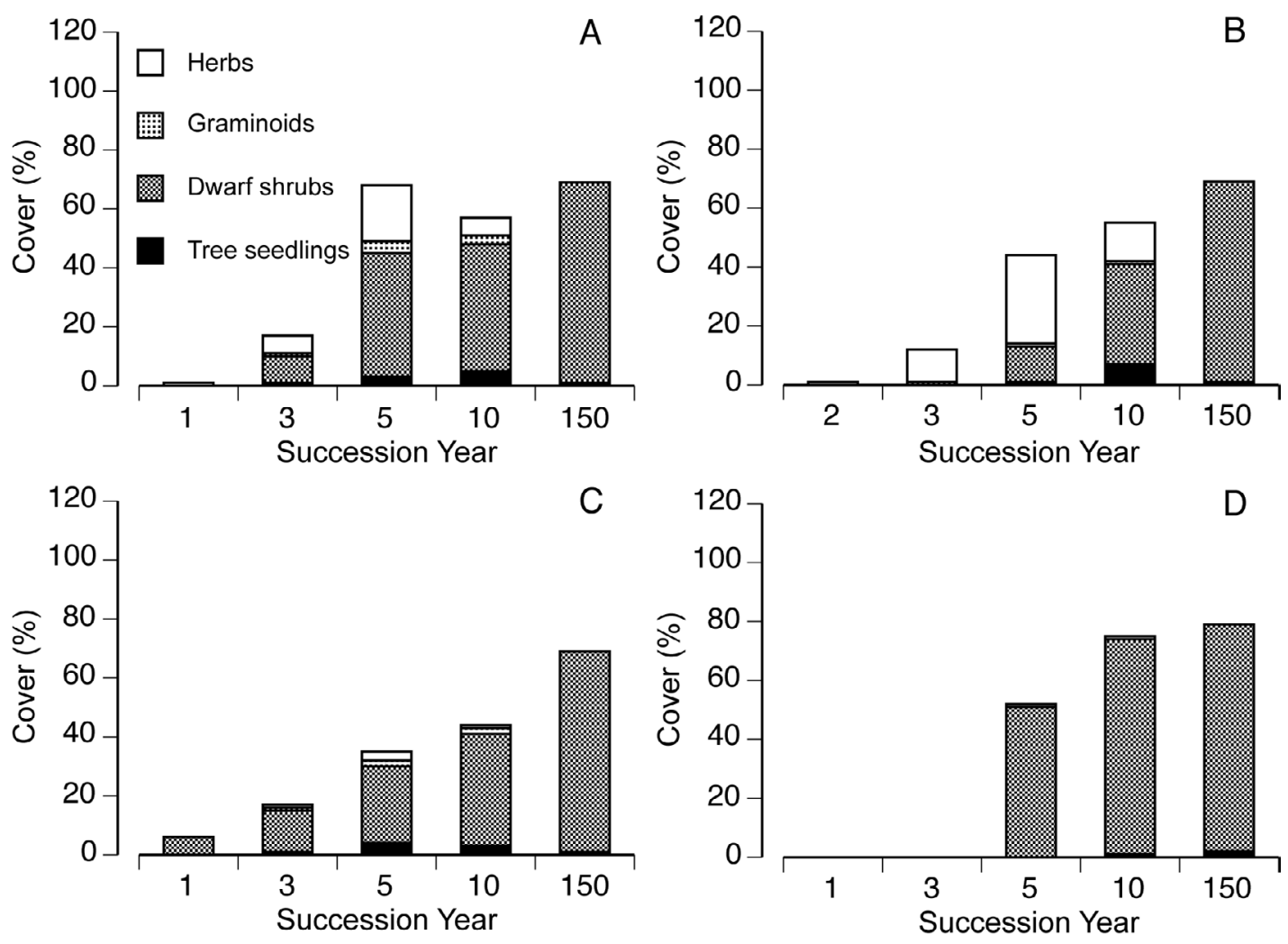

Fig. 3. Mean cover (\%) of the understorey vascular flora in four fire severity 'treatments' left by wildfire. (A) ground and canopy fire at Jäkäläkangas, (B) ground fire on clear-cut figure, (C) ground and partial canopy fire at Jäkäläkangas, and (D) ground fire at Pöytäkangas. Controls (succession year > 80) are different between Jäkäläkangas and Pöytäkangas.

$6(10 \%)$ species were only observed in the control areas. Thus, species richness of the area increased by approximately $40 \%$ [25/(82 - 25)] as a result of the fire. Species richness was relatively even between the 'treatments' during the study period: A had a total of 54 species, B 47 species, C 52 species, D 54 species, and the controls 54 species. These values did not differ from a uniform distribution $\left(\chi^{2}=0.95 ; p=0.92\right)$. After ten years species diversity (Shannon's $H$ ) was higher in the clear-cut patch (B) than at the other sites. Diversity tended to be lowest at site D.

\section{Discussion}

Ordination of the permanent sample plots indicated a convergence of initially relatively different 'treatments' towards a common target (Halpern 1988, Turner et al. 1997). In addition to statistical analysis, visual inspection of the average development in different 'treatments' (Fig. 2B) supported this observation. The three most severely affected 'treatments' approached each other rapidly the first five years, having reached considerable, but not complete resemblance within ten years. Moreover, at all times, the distance to control plots in the ordination increased with increasing disturbance intensity. This indicated increasing change in compositional transition (Halpern 1988) and decreasing succession rate. According to Halpern (1988), multiple successional pathways result from a combination of differences in initial composition and disturbance intensity. Although we did not have any information about the prefire conditions at each site, there was no reason to suspect that initial understorey vegetation would have been uniform across all sites. Nevertheless, it could be concluded that - as overall vegetation composition 

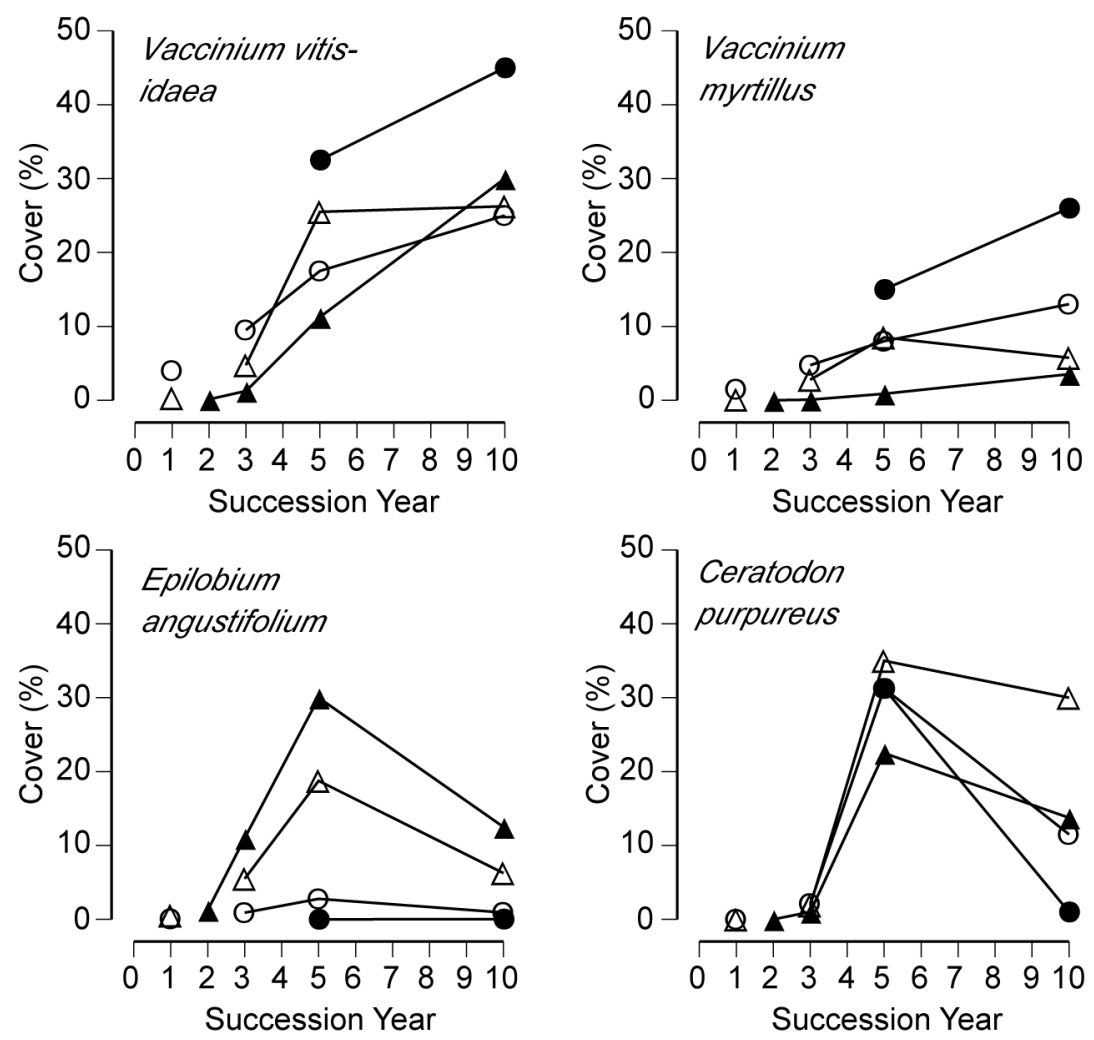

Fig. 4. Mean cover (\%) of dominant understorey species (two dwarf shrubs, one herb and two bryophytes, respectively). Letters in the legend refer to fire intensity 'treatments', for description see Fig. 3.

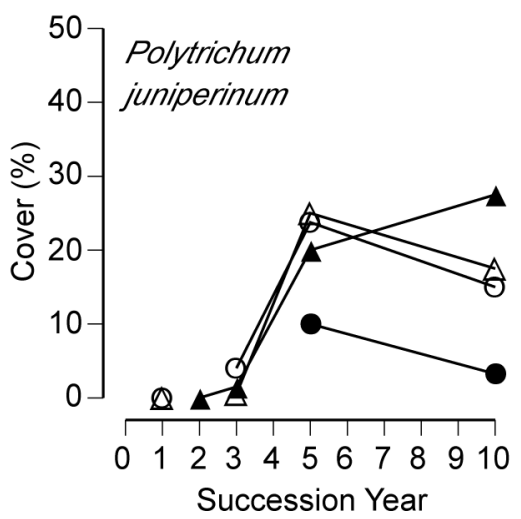

is considered - fire intensity had a clear effect on initial succession in our study area and it clearly had a long-lasting impact on understorey vegetation composition (Schimmel \& Granström 1996, Wang \& Kendal 2005). Moreover, as differences in depth distribution of rhizomes in the soil may be the most important for survival and subsequent resprouting of individuals (Schimmel \& Granström 1996), burn depth was the most obvious explanation to the observed patterns. As humus depth was not measured in this study, we could only speculate on the mechanism behind the observed vegetation patterns.

When the overall surface level succession was inspected in more detail, the different fire intensity 'treatments' seemed to be relatively similar. However, as the statistical analyses indicated, the 'treatments' differed to some extent in total dwarf shrub, herb, and bryophyte coverage. Dwarf shrub coverage gives a reasonable indication of fire severity, as the recovery efficiency of the dominant species' Vaccinium 

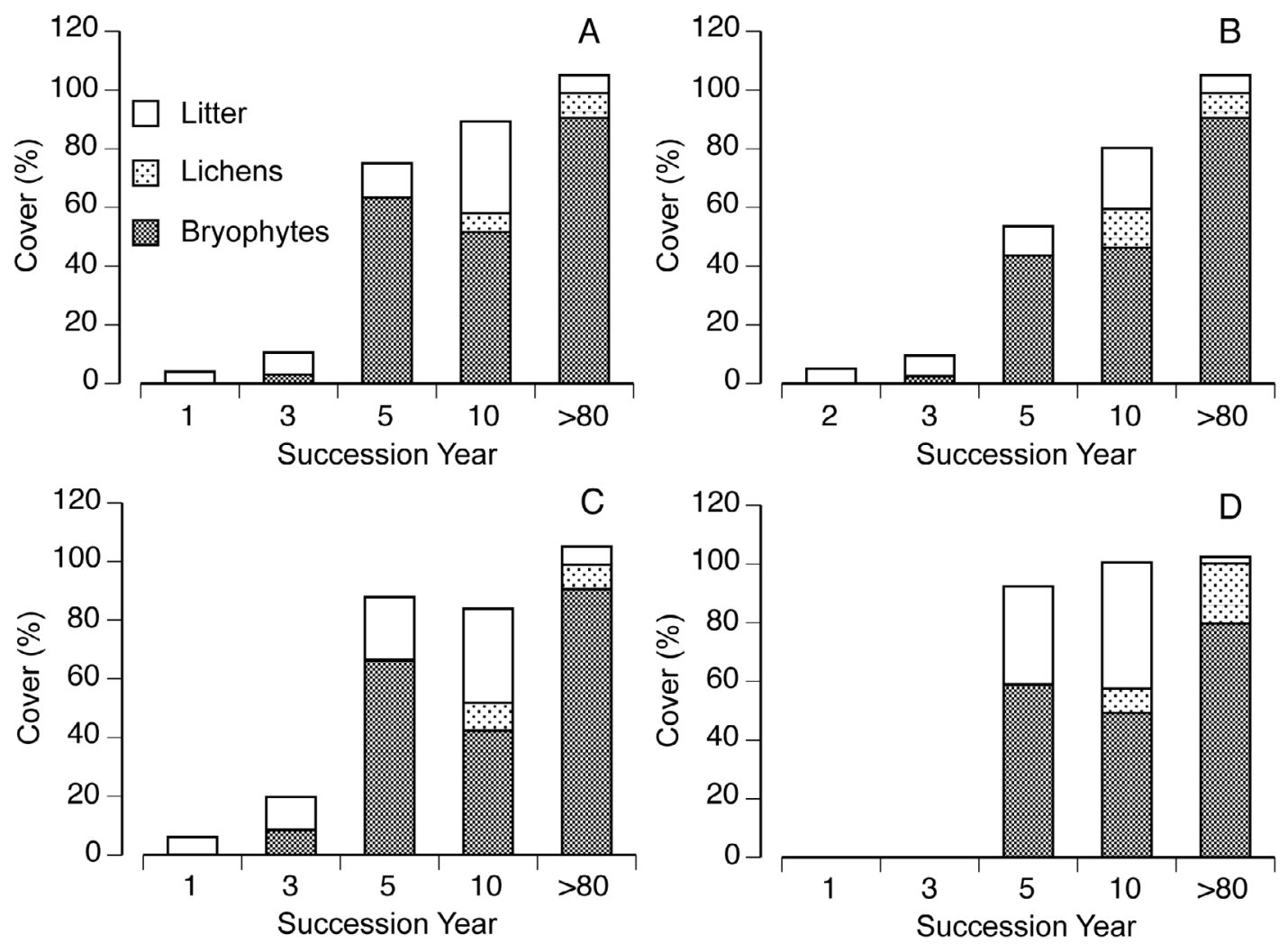

Fig. 5. Mean cover (\%) of the understorey nonvascular flora and ground litter in four fire severity 'treatments' left by wildfire. (A) ground and canopy fire at Jäkäläkangas, (B) ground fire on clear-cut figure, (C) ground and partial canopy fire at Jäkäläkangas, and (D) ground fire at Pöytäkangas. Controls (succession year > 80) are different between Jäkäläkangas and Pöytäkangas.

vitis-idaea and V. myrtillus is clearly dependent on burn depth (Schimmel \& Granström 1996). The lowest total dwarf shrub abundances were observed on the clear-cut patch (B). On the other hand, fire severity may be linked to fuel load (Schimmel \& Granström 1996), but according to Raymond and Petersen (2005) a crown fire is not a prerequisite for high fire severity. Dwarf shrub coverage was higher at the crown fire site (A) as compared with that at the clear-cut patch and ground fire at Jäkäläkangas (C), which also had a small proportion of canopy affected. Reasons for this may be many, but the most probable factor is prefire cover. Other factors (Ryan 2002) such as soil moisture (Hille \& den Ouden 2005) and consumption of fine fuels (Raymond \& Peterson 2005) may also have affected fire severity, whereas light level and particularly soil nutrient balance (Raison 1979, Neary et al. 1999, Giardina \& Rhoades 2001) may have caused dif- ferences in vegetation development due to the previous factors affecting fire severity.

Although the interpretation of dwarf shrub coverage was not conclusive, total herb abundance provided additional information about fire severity. According to Halpern $(1988,1989)$ the abundance of colonizing herbaceous species should increase parallel to increasing fire intensity. In this case, highest herb abundances were observed on the clear-cut patch (B) and the second highest at the crown fire site (A). The ground fire sites (C and D) had hardly any herbs at all. Most herbaceous cover in this study was due to Epilobium angustifolium. As it does not have a seed bank and it is largely absent from forest habitats, this species can be classified as an invader, which regenerates from postfire transported seed (Wang \& Kendal 2005). Cover of E. angustifolium decreased on average from the clear-cut figure to ground fire at Pöytäkan- 
gas (D), and had thus an increased response to apparently increasing fire intensity (Schimmel \& Granström 1996). The differences between ground fires at Jäkäläkangas (C) and Pöytäkangas (D) were most probably due to differences in fire intensity (as indicated by the ordination; Fig. 2). In addition to ground fire, 'treatment' $\mathrm{C}$ was also to some extent affected by crown fire. However, differences in the control areas indicated that there were also differences in initial composition.

The nonvascular flora at the burned sites was dominated namely by two pioneer moss species, Ceratodon purpureus and Polytrichum juniperinum (Wang \& Kendal 2005). These species are typical in early postfire succession (e.g., Sarvas 1937, Schimmel \& Granström 1996). Their regeneration strategy is invasive (colonization by dispersed spores) and they establish well on compact layers of charred humus or exposed mineral soil. Although colonization ability of these species is known to be related to fire intensity (e.g., Schimmel 1993, Schimmel \& Granström 1996), there were no conclusive differences between the 'treatments' in our study.

While there were no differences in species richness between sites, species diversity tended to be initially higher at the more severely affected sites. On a temporal gradient however, increasing species richness, at least in the initial succession, was a logical implication of regeneration after disturbance. In addition, the postfire species composition differed considerably from that in the control areas. Approximately $30 \%$ of all recorded species were only observed during initial succession. Most of these species were relatively rare, as considering percent coverage, but nevertheless they increased local richness. Our results support previous perceptions on an increased postfire diversity (Trabaud \& Lepart 1980, Lindholm \& Vasander 1987, Uotila 2004). Furthermore, $36 \%$ (9) of the species observed only in the burned areas were restricted to one 'treatment' only. This may partially be accounted to fire intensity (Trabaud \& Lepart 1980), but since most of these species were encountered in single sampling plots chance events may have played an important role.

In addition to recognizing the effect of fire intensity, our study also provided some informa- tion about the recovery of understorey vegetation on sub-xeric coniferous forests. According to our results, residual dwarf shrubs (mainly Vaccinium myrtillus and V. vitis-idaea) gained rapidly dominance in the community in all but the most severely affected 'treatment' (Schimmel \& Granström 1996). However, within ten years dwarf shrubs were the dominant life form in all 'treatments'. This clearly indicated that the post-fire communities were mostly dependent on the pre-disturbed plant community (Dyrness 1973, Foster 1985, Rego et al. 1991, Turner et al. 1997), which is a direct consequence of the adaptations of the dominant species to fire disturbance (or to other drastic disturbances).

Our results agree to some extent with earlier findings that species regeneration strategy largely determines their response to fire behaviour (Schimmel \& Granström 1996, Wang \& Kendal 2005). The overall vegetation composition was clearly different between severely and more lightly burned sites. Within the vascular flora invader strategists (namely Epilobium angustifolium) established themselves best at the more severely burned sites. Also, sprouter strategists (namely the dominant dwarf shrub species), were at least initially more abundant at the more lightly burned sites as compared with the severely burned sites (Schimmel \& Granström 1996, Duchesne \& Wetzel 2004, Wang \& Kendal 2005). The differences between our results and those of earlier studies are most probably due to habitat factors (which again translate to differences in initial conditions and general vegetation composition) and differences in realized fire intensity.

\section{Acknowledgements}

We thank two anonymous referees for helpful comments on the manuscript. L. R. received funding from the Nordic Centre of Excellence EcoClim project.

\section{References}

Armour, C. D., Buntings, S. C. \& Neuenschwander, L. F. 1984: Fire intensity effects on the understory in ponderosa pine forest. - J. Range Manage. 37: 44-49.

Arocena, J. M. \& Opio, C. 2003: Prescribed fire-induced 
changes in properties of sub-boreal forest soils. - Geoderma 113: 1-16.

Crawley, M. J. 2002: Statistical computing. - John Wiley \& Sons Ltd., Chichester.

Duchesne, L. C. \& Wetzel, S. 2004: Effects of fire intensity and depth of burn on lowbush blueberry, Vaccinium angustifolium, and velvet leaf blueberry, Vaccinium myrtilloides, production in eastern Ontario. - Can. Field-Nat. 118: 195-200.

Dyrness, C. T. 1973: Early stages of plant succession following logging and burning in the western cascades of Oregon. - Ecology 54: 57-69.

Feller, M. C. 1982: The ecological effects of slash burning with particular reference to British Columbia: a literature review. - Land Management Report No. 13, B.C. Ministry of Forests, Canada.

Feller, M. C. 1983: Impacts of prescribed fire (slashburning) on forest productivity, soil erosion and water quality on the coast. - In: Brittish Columbia Minnesota Forestry and Land Management Report: 57-91. B.C. Ministry of Forests, Canada.

Foster, D. R. 1985: Vegetation development following fire in Picea mariana (black spruce) - Pleurozium forest of South-Eastern Labrador, Canada. - J. Ecol. 73: 517-534.

Giardina, C. P. \& Rhoades, C. C. 2001: Clear-cutting and burning affect on soil nutrient supply, phosphorus fraction and seedling growth in soils from a Wyoming a lodgepole pine forest. - For. Ecol. Manage. 140: $19-28$.

Halpern, C. B. 1988: Early successional pathways and the resistence and resilience of forest communities. - Ecology 69: 1703-1715.

Halpern, C. B. 1989: Early succession patterns of forest species: interactions of life history traits and disturbance. - Ecology 70: 704-720.

Hämet-Ahti, L., Suominen, J., Ulvinen, T. \& Uotila, P. 1998: Retkeilykasvio, 3rd ed. - Luonnontieteellinen keskusmuseo, Kasvimuseo, Helsinki.

Heinselman, M. L. 1973: Fire in virgine forests of the Boundary Waters Canoe Area, Minnesota. - Quaternary Res. 3: 329-382.

Hille, M. \& den Ouden, J. 2005: Fuel load, humus consumption and humus moisture dynamics in central European Scots pine stands. - Int. J. Wildland Fire 14: 153-159.

Holmåsen, I. 1998: Lavar och mossor, 4. - Stenström Interpublishing AB.

Johnson, E. A. 1992: Fire and vegetation dynamics: studies from North American boreal forest. - Cambridge University Press, Cambridge, UK.

Legendre, P. \& Legendre, L. 1998: Numerical ecology, 2nd English ed. - Elsevier, Amsterdam.

Lehtonen, H. \& Huttunen, P. 1997: History of forest fires in eastern Finland from the fifteenth century AD - the possible effect of slash-and-burn cultivation. - The Holocene 7: 223-228.

Lindholm, T. \& Vasander, H. 1987: Vegetation and stand development of mesic forest after prescribed burning. - Silva Fennica 27: 145-157.

Neary, D. G., Klopatek, C. C., DeBano, L. F. \& Ffolliott,
P. F. 1999: Fire effects on belowground sustainability: a review and synthesis. - For. Ecol. Manage. 122: $51-71$.

Økland, R. H. 1990: Vegetation ecology: theory, methods and applications with reference to Fennoscandia. - Sommerfeltia Suppl. 1: 1-233.

Økland, R. H. 2000: Understorey vegetation development in North Finnish Picea forests after disturbance: re-analysis of Sirén's data. - J. Veg. Sci. 11: 533-546.

Pielou, E. C. 1975: Ecological diversity. - John Wiley \& Sons, New York.

Pietikäinen, J. \& Fritze, H. 1992: Microbial biomass and activity in the humus layer following burning: short term effects of teo fires. - Can. J. For. Res. 23: 1275-1285.

Raison, R. J. 1979: Modification of soil environment by vegetation fires, with particular reference to nitrogen transformations: a review. - Plant \& Soil 51: 73-108.

Raymond, C. L. \& Peterson, D. L. 2005: Fuel treatments alter the effects of wildfire in a mixed-evergreen forest, Oregon, USA. - Can. J. For. Res. 35: 2981-2995.

Rego, F. C., Buntings, S. C. \& DaSilva, J. M. 1991: Changes in understory vegetation following prescribed fire in maritime pine forests. - For. Ecol. Manage. 41: 21-31.

Ruokolainen, L. \& Salo, K. 2006a: Differences in performance of four ordination methods on a complex vegetation dataset. - Ann. Bot. Fennici 43: 269-275.

Ruokolainen, L. \& Salo, K. 2006b: The succession of boreal forest vegetation during ten years after slash-burning in Koli National Park, eastern Finland. - Ann. Bot. Fennici 43: 363-378.

Ryan, K. C. 2002: Dynamic interactions between forest structure and fire behavior in boreal ecosystems. - Silva Fennica 36: 13-39.

Sarvas, R. 1937: Havaintoja kasvillisuuden kehityksestä Pohjois-Suomen kuloalueilla. - Silva Fennica 44: 32-64.

Schimmel, J. 1993: On fire. Fire behaviour, fuel succession, and vegetation processes to fire in the Swedish boreal forest. - Department of Forest Vegetation Ecology, Swedish University of Agricultural Sciences.

Schimmel, J. \& Granström, A. 1996: Fire severity and vegetation response in the boreal Swedish forest. - Ecology 77: 1436-1450.

Shafi, M. I. \& Yarranton, G. A. 1973: Vegetational heterogeneity during secondary (postfire) succession. - Can.J. Bot. 51: 73-90.

Simard, D. G., Fyles, J. W., Pare, D. \& Nguyen, T. 2001: Impacts of clearcut harvesting and wildfire on soil nutrient status in Quebec boreal forest. - Can. J. Soil Sci. 81: 229-237.

Trabaud, L. \& Lepart, J. 1980: Diversity and stability in garrigue ecosystems after fire. - Vegetatio 43: 49-57.

Turner, M. G. \& Romme, W. H. 1994: Landscape dynamics in crown fire ecosystems. - Landsc. Ecol. 9: 59-77.

Turner, M. G., Romme, W. H., Gardner, R. H. \& Hargrove, W. W. 1997: Effects of fire size and pattern on early succession in Yellowstone National Park. - Ecol. Monogr. 67: 411-433.

Uotila, A. 2004: Vegetation patterns in managed and seminatural boreal forests in eastern Finland and Russian Karelia. - Faculty of Forestry, University of Joensuu. 
Wang, G. G. \& Kendal, K. J. 2005: Effects of fire severity on early development of understory vegetation. - Can. J. For. Res. 35: 254-262.

Wardle, D. A., Zackrisson, O., Hörnberg, G. \& Gallet, C.
1997: The influence of island area on ecosystem properties. - Science 277: 1296-1299.

Zackrisson, O. 1977: Influence of forest fires on North Swedish boreal forest. - Oikos 29: 22-32.

Appendix. Average percent cover and frequency of all species (in field layer), observed during the study period, by different areas within the study area $(A=$ crown fire at Jäkäläkangas; $B=$ fire on a clear-cut figure; $C=$ ground fire at Jäkäläkangas; $D$ = ground fire at Pöytäkangas; Control = combined values for Control on Jäkäläkangas and Control on Pöytäkangas).

\begin{tabular}{|c|c|c|c|c|c|c|c|c|c|c|}
\hline & \multicolumn{2}{|c|}{ A } & \multicolumn{2}{|c|}{ B } & \multicolumn{2}{|c|}{ C } & \multicolumn{2}{|c|}{ D } & \multicolumn{2}{|c|}{ Control } \\
\hline & Cover & Freq. & Cover & Freq. & Cover & Freq. & Cover & Freq. & Cover & Freq. \\
\hline \multicolumn{11}{|l|}{ Trees } \\
\hline Betula pendula & 0.6 & 7 & 1.4 & 11 & 0.3 & 5 & 0.1 & 1 & 0.1 & 6 \\
\hline Betula pubescens & 0.1 & 5 & 0.1 & 4 & 0.3 & 1 & 0.2 & 3 & & \\
\hline Picea abies & - & 1 & & & - & 3 & & & 0.6 & 14 \\
\hline Pinus sylvestris & 1 & 13 & 0.4 & 12 & 1.7 & 13 & 0.1 & 8 & 0.5 & 1 \\
\hline Populus tremula & 0.1 & 4 & & & & & 0.1 & 3 & 0.1 & 1 \\
\hline Salix caprea & 0.1 & 3 & 0.1 & 5 & - & 1 & - & 1 & & \\
\hline Salix phylicifolia & & & - & 1 & & & - & 1 & 0.1 & 6 \\
\hline Salix sp. & 0.3 & 7 & - & 2 & - & 1 & & & & \\
\hline Salix starkeana & - & 1 & & & & & 0.1 & 1 & & \\
\hline $\begin{array}{l}\text { Sorbus aucuparia } \\
\text { Dwarf shrubs }\end{array}$ & 0.1 & 7 & - & 1 & & & & & & \\
\hline \multicolumn{11}{|l|}{ Dwarf shrubs } \\
\hline $\begin{array}{l}\text { Calluna vulgaris } \\
\text { Empetrum nigrum }\end{array}$ & 4.7 & 7 & & & - & 1 & & & 0.1 & $\begin{array}{r}2 \\
14\end{array}$ \\
\hline Empetrum nigrum & - & 2 & - & 1 & - & 1 & - & 1 & 17.9 & 14 \\
\hline Ledum palustre & 0.1 & 3 & & & & & & & & \\
\hline Vaccinium myrtillus & 4.3 & 16 & 1.1 & 1 & 6.8 & 16 & 20.5 & 8 & 21.4 & 14 \\
\hline Vaccinium uliginosum & 0.3 & 7 & - & 2 & - & 1 & 2.7 & 6 & 5.5 & 14 \\
\hline Vaccinium vitis-idaea & 14.2 & 16 & 10.7 & 16 & 13.6 & 16 & 38.8 & 8 & 28.2 & 14 \\
\hline \multicolumn{11}{|l|}{ Graminoids } \\
\hline Agrostis capillaris & & & - & 1 & & & & & & \\
\hline Carex globularis & & & - & 1 & - & 1 & & & & \\
\hline Deschampsia flexuosa & 2.1 & 11 & 0.4 & 8 & 1.4 & 11 & 0.5 & 6 & - & 2 \\
\hline Luzula pilosa & - & 1 & & & & & & & & \\
\hline \multicolumn{11}{|l|}{ Herbs } \\
\hline Antennaria dioica & & & & & & & 0.1 & 1 & & \\
\hline Epilobium angustifolium & 7.8 & 14 & 13.7 & 15 & 1.2 & 13 & - & 1 & - & 3 \\
\hline Melampyrum pratense & - & 2 & - & 1 & - & 2 & 0.3 & 3 & 0.3 & 12 \\
\hline Pyrola media & - & 1 & & & & & & & & \\
\hline Taraxacum officinale & - & 6 & - & 4 & & & & & & \\
\hline \multicolumn{11}{|l|}{ Pteridophyta } \\
\hline Diphasiastrum complanatum & & & & & & & - & 2 & & \\
\hline Gymnocarpium dryopteris & & & - & 2 & & & & & & \\
\hline Lycopodium annotinum & - & 2 & - & 2 & - & 3 & & & & \\
\hline Lycopodium clavatum & & & - & 1 & - & 2 & & & & \\
\hline \multicolumn{11}{|l|}{ Bryophytes } \\
\hline Aulacomnium palustre & - & 1 & 0.1 & 1 & - & 2 & 0.7 & 5 & 0.1 & 2 \\
\hline Barbilophozia attenuata & & & & & & & - & 1 & - & 2 \\
\hline Brachythecium reflexum & & & & & & & - & 2 & - & 2 \\
\hline Brachythecium salebrosum & & & & & & & & & - & 2 \\
\hline Buxbaumia aphylla & & & & & & & - & 2 & & \\
\hline Calystegia intermedia & & & & & & & & & - & 2 \\
\hline Calystegia sp. & - & 1 & & & & & & & & \\
\hline Cephalozia leucantha & & & & & & & - & 1 & - & 2 \\
\hline Ceratodon purpureus & 16.7 & 12 & 9.3 & 12 & 11.2 & 12 & 16.1 & 8 & & \\
\hline Dicranum angustum & & & & & & & - & 2 & & \\
\hline
\end{tabular}


Appendix. Continued.

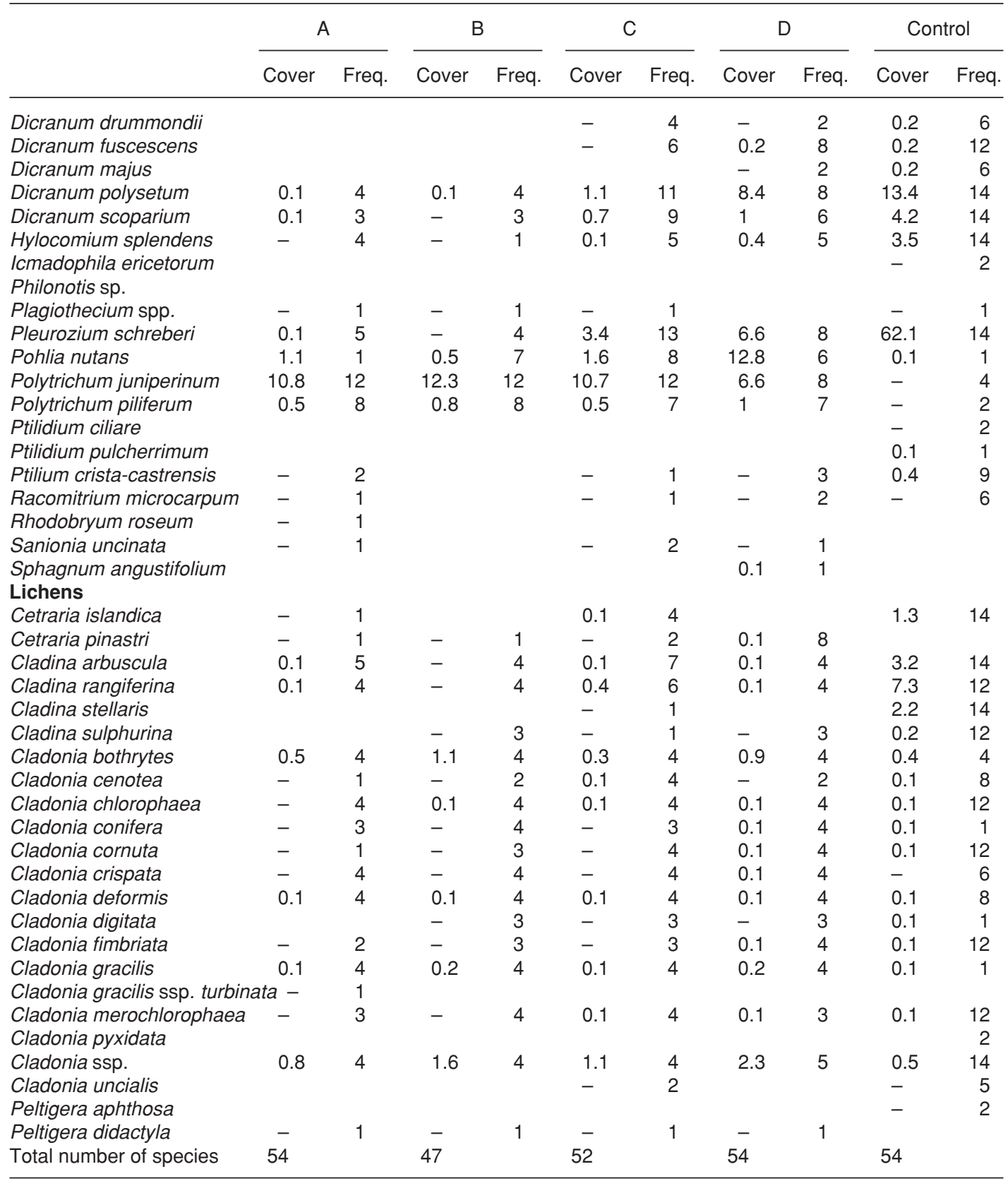

